\title{
H3C13 wt Allele
}

National Cancer Institute

\section{Source}

National Cancer Institute. H3C13 wt Allele. NCI Thesaurus. Code C154648.

Human $\mathrm{H} 3 \mathrm{C} 13$ wild-type allele is located in the vicinity of $1 \mathrm{q} 21.2$ and is approximately $1 \mathrm{~kb}$ in length. This allele, which encodes histone H3.2 protein, plays a role in the incorporation of DNA into nucleosomes. 